\title{
The Research-Teaching Nexus: A Case Study of Students' Awareness, Experiences and Perceptions of Research
}

\author{
Mick Healey1, Fiona Jordan², Barney Pell ${ }^{3}$ and Chris Short ${ }^{1}$ \\ ${ }^{1}$ University of Gloucestershire; ${ }^{2}$ University of the West of England; ${ }^{3}$ University of Stuttgart
}

\section{SUMMARY}

This paper presents a case study of students' awareness, experiences and perceptions of research in a 'new' university in the UK. The findings are based on a questionnaire of almost 200 students and five small group interviews. Many of the students participating in this research perceived clear benefits to their learning from staff research, including being taught by enthusiastic staff, enhanced staff credibility, and the reflected glory of being taught by well-known researchers. However, they also perceived disadvantages, particularly with regard to staff availability and did not believe that staff research should take priority over their needs as learners. They recognised that their awareness of the nature of research and the development of research skills increased most when they were actively involved in undertaking research projects. Several students also perceived benefits for future employment from their participation in research activities. The questionnaire has been used by several other universities around the world to benchmark their practices.

Key words: Research-teaching nexus; research and teaching linkages; student experience; research awareness, experiences and perceptions

\section{"We are the university at least while we are here" (A student respondent)}

\section{RESEARCH AND TEACHING LINKS}

The subject of linking research and teaching is attracting significant international attention from both policy makers and academics. There is a growing body of research on the topic (see for instance books by Barnett, 2005; Brew, 2001; 2006; Jenkins et al., 2003; Kreber, 2006). The desire to promote international competitiveness is encouraging many governments to concentrate their research funding in fewer higher education institutions. This has led some to question the need for undergraduate students to be taught in a research environment. For example, in Australia the Bradley review questioned whether teaching-only universities should be established (Australian Government, 2008). This debate occurred five years ago in the UK following the publication of the Government White Paper on Higher Education (DfES, 2003). However, in the face of sustained opposition and heeding the advice of the Research Forum (2004), the government acknowledged the need to support 'new' universities to develop 'research-informed teaching environments' (DfES, 2004).

In contrast to the activities of governments, academics have argued that students gain benefits from being taught by active researchers and being involved directly in the research process (e.g. Healey, 2005a; Jenkins et al., 2003; Lee, 2004), although the drawbacks for students of excessive attention being paid to research have also been voiced (e.g. Jenkins, 1995; Pocklington \& Tupper, 2002). Many of the studies examining the research-teaching nexus have focused on establishing whether or not there is a relationship between these two activities and exploring the staff experience of the relationship (e.g. Brew, 2001; Durning \& Jenkins, 2005; Hattie and Marsh, 1996; Robertson \& Bond, 2001; 2005). Recent work has begun to focus on what institutions, departments, disciplines and individuals may do to enhance the linkages for the benefit of student learning (e.g. Healey, 2005a; b; Jenkins \& Healey, 2005; Jenkins et al., 2003; 
Jenkins et al., 2007). However, relatively few studies have examined teaching-research nexus from the perspective of the students themselves (e.g. Jenkins et al., 1998; Zamorski, 2002). Whilst some research has begun to explore the student experience of undertaking research projects themselves (e.g. Kinkead, 2003; Ryder, 2004; Seymour et al., 2004), fewer have examined the variety of ways in which students may experience research in universities more generally throughout their studies (Table 1).

\section{(Table 1 about here)}

Those studies which have been undertaken have concluded that whilst students derived clear benefits from staff research, they also perceived disadvantages, primarily where they believed that research was prioritised over teaching. These findings are tentative in that most of the studies were based on relatively small samples dealing with either undergraduate or postgraduate students. The study reported here synthesised previous research on these issues to design a systematic survey of the way in which students are aware, experience and perceive, research in an institutional context. The project on which this paper is based set out to explore the issue both quantitatively and qualitatively in a 'new' university through eliciting the views of both postgraduate and undergraduate students.

It is acknowledged that the terminology used to describe 'research', and 'teaching' may itself be contested and subject to differing interpretations (Brew, 1999; Healey, 2005a; Jenkins et al., 2003). However, following the work of Griffiths (2004) and Healey (2005a) it is generally accepted that students may experience research in four main ways, although the terms used to describe them vary and are often used interchangeably:

- Research-led: where students learn about research findings, the curriculum content is dominated by faculty research interests, and information transmission is the main teaching mode;

- Research-oriented: where students learn about research processes, the curriculum emphasises as much the processes by which knowledge is produced as learning knowledge that has been achieved, and faculty try to engender a research ethos through their teaching;

- Research-based: where students learn as researchers, the curriculum is largely designed around inquiry-based activities, and the division of roles between teacher and student is minimised.

- Research tutored: where students learn in small group discussions with a teacher about research findings.

Most universities claim that their teaching and research are closely linked. This paper examines the extent to which the students at one case study university experience this linkage. This university operates within a broad definition of the ways in which students may engage with research encompassing: "student engagement from induction to graduation, individually and in groups, in research and inquiry into disciplinary, professional and community-based problems and issues, including involvement in knowledge exchange activities" (Childs et al., 2007).

\section{METHODS}

The case study institution within which this study was based, the University of Gloucestershire, received University title in 2001 , although the institution dates back to 1847 . The university is medium in size with approximately 10,000 students and delivers programmes of study primarily centred on vocational subjects and some liberal arts. In the 2001 Research Assessment Exercise (RAE) $40 \%$ of staff were entered. As the purpose of the project was to investigate student experiences of research over the course of their studies, final year undergraduate and 
taught postgraduate students were targeted. Many previous studies have relied on one method, such as a questionnaire (Willis et al., 1999) or focus groups (Jenkins et al., 1998). In this study the data collection was a two-stage process, where the mixing (or triangulation) of methods had the benefit of providing different fixes on the reality under investigation (McNeill, 1990). This approach is supported by Lindsay et al. $(2002,11)$ who note that "qualitative and quantitative analyses can be mutually illuminating and supportive."

The quantitative aspect of the research was an email questionnaire comprising of a series of open and closed questions and Likert scales. This was followed up with five small discussion groups with students to add a qualitative dimension to the work. The content of the questionnaire was derived from the existing literature, summarised in Table 1, and expanded to explore new areas of students' awareness, experience and perceptions of research. A copy is available at: http://trnexus.edu.au/uploads/downloads/TR\%20Questionnaire.pdf. An analysis of the findings from the questionnaire informed the topics for the discussion groups. The questionnaires were sent out in February/March 2002 to 2,450 students of whom 196 responded, a response rate of $8 \%$. The division of the responses by, level of study, sex and subject studied is shown in Table II. Whilst low, this is not unusual for a survey of this type (De Vaus, 2002). We estimate that as many as a third of the sample might not have been able to access the survey because their mailboxes were full; if this was the case the response rate is closer to $12 \%$. We do not know how many more simply rarely accessed their university email accounts. The low response rate means that the findings should not be taken as representative of all students in the University. Nevertheless, almost 200 responses is considerably more than that obtained by most previous studies and some valuable information was gleaned from the questionnaire to assist in designing the qualitative phase of the study.

\section{(Table I/ about here)}

The inventory of student experience provided by the questionnaire informed small group discussions designed to elicit richer, qualitative data providing further insight into the social reality of the individuality of student experience. Five small discussion groups were organised. These consisted of between two and five students and comprised of 15 undergraduates and three postgraduates; seven from the School of Leisure, Tourism, Hospitality and Sport (LTHS), four from the Business School (BS) and seven from other schools (OS) (Pell, 2003). The topics addressed in the groups were drawn from the categories used in the questionnaire and organised into broad topic headings. These were used to code transcriptions of the group discussions and the transcripts were then subject to a process of discourse analysis (Silverman, 1993). The findings from both phases of the study are integrated within the discussion below.

\section{ANALYSIS}

The findings are presented in two parts. The first part analyses students' passive experiences (awareness) and active experiences of (involvement in) research. The second part explores the extent to which students experienced staff involvement in research as having a positive or negative impact on their teaching and learning.

\section{Passive and active experiences}

The students were asked about where and how they heard about staff research activities and about the types of research outputs that they had encountered during their time at university. Two-thirds of the participants in this study indicated that they were unaware of the research expertise of the university when they applied, with postgraduates being only slightly more aware than undergraduates. This counters, at least in respect of this particular new university, the perception that the research reputation of a university is a key attraction for students. This finding may reflect the vocational orientation of this university and is interesting in the light of the 
introduction of tuition fees in UK universities and what some predict will be a shift in student choice towards employability-focussed programmes and institutions (Foskett et al., 2006).

Participants in this study believed that research was something you became aware of during your studies rather than prior to them. The four most recognised sources of information on this topic were identified by both undergraduate and postgraduate students as: notice board displays (59\%); academic articles and books (52\%); research seminars (50\%); and research exhibitions (40\%) but almost half of the students surveyed were not aware of the research in which their staff were engaged.

Students in the group interviews elaborated on this point:

I mean, apart from things like my dissertation tutor's been writing a book, which I know about, but ... it's only because she was interested in something that I was interested in that I knew she was writing a book, but there's no wider kind of publicity that there is research going on ....

[Level III female, Geography student]

There was evidence to suggest that students expected staff to share with them their experiences of research and when this did not occur there was a sense of disappointment on the part of the students. Although knowledge and awareness of research was relatively low among the students, $51 \%$ agreed with the statement that 'Staff involved in research and/or consultancy are more enthusiastic about their subject, while only $14 \%$ disagreed.

Previous studies have shown that students are most likely to benefit from linkages between teaching and research when they are actively engaged in teaching and learning activities through which their own research skills are developed (Brew, 1999; Elton, 2001). The findings of this study support these claims, as $47 \%$ of participants agreed to the statement the most effective teaching is when the lecturer involves us in aspects of the research process', compared to $10 \%$ who disagreed. As shown in Table III by far the most frequent active experiences highlighted by students in this study concerned the undertaking of a dissertation or thesis $(72 \%)$ or an independent project within a module (54\%).

\section{(Table III about here)}

These findings resonate with those of Willis et al. (1999) and are reflective of the value of a research-based curriculum (Griffiths, 2004; Healey, 2005a) where students learn about research by engaging in it. Furthermore, 39\% of respondents agreed with the statement that they 'had learnt most when undertaking my own research project/dissertation as against $21 \%$ who disagreed with this statement. The student's experiences of research within their learning was often significantly shaped by the relationship with their dissertation tutor and final year lecturers. The value of working with research active staff in undertaking the dissertation was highlighted by this postgraduate student:

The research conducted by [name of tutor] and [name of grad. student] was a significant factor in determining my dissertation topic. The work was published, but having access to both of them to discuss their work in particular and my dissertation in general helped greatly to clarify issues and define my research area. I also think that the research being done in [subject area] has contributed to my desire to concentrate in this area, and to develop my own consultancy skills.

[Postgraduate, male MBA student]

Around half of the respondents said they had heard a member of staff discuss their research within a module (57\%), listened to a guest lecturer discussing their research (44\%), or read a 
research paper/report by a member of staff (40\%). Only $5 \%$ or less had attended a researchbased conference, with $8 \%$ involved as participants in research projects run by members of staff.

Large variations occurred in active experiences between different discipline areas within the university. The number 'being involved in practical activities' within LTHS is $43 \%$ compared to only $9 \%$ in BS. The average among other areas of the university was $33 \%$. This was reinforced by the fact that $74 \%$ of the LTHS students and $67 \%$ of those from the other areas had undertaken an independent project compared to only $37 \%$ of BS students. These variations may relate to different disciplinary practices (traditions) being reflected in curriculum design and research cultures, such as whether or not a dissertation or project work is considered a compulsory element of a programme. In the current climate of UK HE, this is an important area for universities to consider in that some studies suggest that as fee payers students may adopt a more instrumentalist approach to their studies, eschewing those modules (such as dissertations and Research Methods) perceived as being especially academically challenging (Harrington and Booth, 2003). The findings of this project highlight the importance of retaining such projects in that they have an important part to play in encouraging students to be active members of 'communities of inquiry' (Brew, 2003; Healey, 2005a; Le Heron et al., 2006; Robertson and Bond, 2005).

\section{Positive and negative experiences}

Previous investigations of the teaching-research nexus have suggested that there may be both benefits and disadvantages to students in staff undertaking these activities (Lindsay et al., 2002; Zamorski, 2002). Within the questionnaire used in this study the students were given a list of positive and negative categories associated with the links between research and teaching, from which they could tick any or all that applied. The introductory question asked whether 'the involvement of staff in research and/or consultancy had a positive (or negative) impact on your learning'? There were three times as many positive impacts as negative ones reported.

\section{(Table IV about here)}

The positive responses, shown in Table IV, can be divided into two categories. Firstly, there are those where there was an impact on the quality of teaching and credibility. Over half (52\%) of respondents felt that staff involvement in research had increased their own understanding of the subject, with $42 \%$ agreeing it had stimulated their interest and enthusiasm for the subject. Postgraduates were particularly aware of the benefit in terms of methodological issues (64\%) compared to undergraduates (37\%).

Within the discussion groups this enthusiasm was evident in comments such as 'making it real', 'more enthusiasm', 'up-to-date', 'cutting edge', 'different style- not just talking' and 'translating it to my level'.

... I think it's terribly important from a teaching point of view that they know what they're talking about, they're up to date with what the research is and what people are saying about the subject, and they're making a contribution to that [subject]. ... It can only enhance teaching .... and it [consultancy] obviously brings in money to the university and it also (highlights) ... real-life experiences ....

[Level III, male Business Management student]

Only a small proportion of undergraduates believed involvement in research motivated them to consider postgraduate study (10\%) or a career based around research (4\%). However, on the issue of future prospects it was clear from the discussion groups that students saw the inclusion of research as good for their employment prospects and experience. This primarily related to 
their acquisition of independent learning skills and enhanced development of research skills, as well as the outside contacts that this type of research enabled them to build up:

You've got a report ... you can take that into an interview with you, and say, ... here's the degree certificate and this is what I can do.

(Level III, male, Computing student)

There is a sense here that students appreciated the 'added value' that such skills afforded them. Given the introduction of fees and the potential shift towards more career-related study (Harrington and Booth, 2003), student perceptions of staff research as cutting edge and industrylinked may become increasingly significant in influencing their active engagement in learning. Despite recognition of the benefits they accrued from staff research, a minority of students also identified negative experiences, primarily associated with a perceived lack of availability of staff as shown in Table $\mathrm{V}$.

\section{(Table V about here)}

In the opinions of these students, some staff prioritised research activities over teaching and learning, a facet of the teaching-research nexus also identified by Jenkins et al. (1998). For this minority of students not being able to access staff when they needed assistance was a source of frustration as illustrated in this quote:

The lecturer who you actually need won't even give you five minutes, and when you do actually make an appointment with him to go and see him, he rushes you so much that you forget what you want to ask him in the first place because he's so scary and rushes you through everything.

[Level III, female, Sports \& Exercise Science student]

\section{DISCUSSION AND CONCLUSIONS}

Care should always be taken when generalising findings from a case study with restricted subject breadth (no physical sciences, engineering, medicine or languages) and a relatively low response rate to the questionnaire. Nevertheless taken together with the qualitative findings from the small group interviews, the findings paint a clear picture of the awareness, experiences and perceptions of research held by over 200 students in a new university.

The extent to which participants in this study were aware of staff research varied and exposure to staff research was often skewed towards the later stages of their programmes of study, especially in the case of undergraduates. Active interest in, and engagement with, staff research was most evident when students were undertaking a dissertation or independent project, meaning that their overall experience of research was significantly shaped by the relationship with their dissertation tutor and final year lecturers. In an increasingly instrumentalist culture of $\mathrm{HE}$, one of the challenges is for universities to recognise that despite resistance on the part of some students to undertaking projects and dissertations which they can perceive to be especially challenging (Harrington and Booth, 2003) these subjects have an important part to play in developing students as researchers and active learners.

Students readily identified a range of benefits that they felt derived from their tutors' interests in research. For these students the most positive facet of being taught by research-active staff was considered to be their enhanced enthusiasm and motivational abilities. They tended to associate staff involvement in research with up-to-date knowledge and believed such tutors to be more able to assist their own research. This finding reiterates one of the benefits to students identified 
in previous research (Neumann, 1994; Jenkins et al., 1998), namely the insight they gain into staff as people and learners.

An effective means of ensuring that students benefit from staff research was shown to be the adoption of a research-based approach to the curriculum, where students were encouraged to develop their own research skills. This is in line with the arguments of Elton (2001) and Healey (2005a) that inquiry-based learning is a powerful way of linking research and teaching. It can foster a critical and inter-disciplinary approach and help develop many of the skills demanded by employers. Such an approach encourages co-learning between staff and students (Le Heron et al., 2006) and may both enhance student learning and lead to greater synergies between research and teaching (Healey, 2005a). Since this study was undertaken the case study university has made the teaching-research nexus an important feature of its teaching and learning strategy and, through the Centre for Active Learning (a Higher Education Funding Council for England Centre for Excellence in Teaching and Learning), is promoting an inquirybased learning model throughout the institution.

As with previous studies (e.g. Jenkins et al., 1998), the primary drawback of staff research activity, though identified by only a minority of participants in this study, was their perceived lack of availability to students particularly at critical times. In some instances students associated staff engagement in research with being less interested in teaching and in spending a reduced amount of time with their students. In an increasingly consumerist culture of HE, with many universities likely to prioritise 'customer care' for students (Foskett et al. 2006), there is potentially a tension here that will need to carefully managed by institutions.

These findings suggest that universities could usefully adopt, or rediscover in some instances, the 'mission-idea', of returning students to the centre of their activities, and providing a guiding ethos of inquiry and scholarship for all members of the academic community. An emphasis here on scholarship, as conceptualised by Boyer (1990), is fundamental as it tends to encourage student-centred and reflective teaching practice, as well as focusing on inquiry in the curriculum and the induction of students into a community of practice where the establishment of knowledge is the shared goal. The focus on the construction of knowledge through inquiry also responds to calls from Brew (2001) to fit higher education for a world of 'super-complexity' (Barnett, 2000) and Jenkins \& Healey (2009) for undergraduate research and inquiry to be for all students in all HE institutions.

Since the research reported here was undertaken, several others have used our questionnaire in a variety of institutions in Europe, North America and Australia, some of which have been published (Turner et al., 2008; Verburgh et al., 2006). As more studies using this inventory become available, institutions will have benchmarks to evaluate the experiences of their own students against. Generally speaking students in the more research-intensive universities have greater awareness of research, but students at Gloucestershire were as frequently engaged in doing research. This finding supports the contention that active learning through enquiry is as relevant a way of linking research and teaching in less-research intensive universities as it is in more research-intensive ones. Not least it has shown the importance of exploring the student experiences and perceptions of disciplinary research and their experience of research within their courses. This has important implications regarding how courses and the corresponding curriculum are developed. Research such as this can also be compared with the experiences and perceptions of staff, thereby increasing our understanding of the teaching and research nexus. 


\section{REFERENCES}

Australian Government (2008) Review of Australian Higher Education Discussion Paper June 2008. (Canberra: Commonwealth of Australia) http://www.dest.gov.au/HEreview. (Accessed 16 September 2008).

Barnett, R. (2000) Realizing the University: In an age of super-complexity (Buckingham: Open University Press).

Barnett, R. (Ed.) (2005) Reshaping the university: new relationships between research, scholarship and teaching (Maidenhead: Open University Press).

Blackmore, P. \& Cousin, G. (2003) Linking teaching and research through research-based learning, Educational Developments, 4(4), pp.24-27.

Boyer, E. L. (1990) Scholarship Revisited. (Princeton University NJ: Carnegie Foundation for the Advancement of Teaching).

Breen, R. \& Lindsay, R. (1999) Academic research and student motivation, Studies in Higher Education, 24 (1), pp.75-93.

Brew, A. (1999) Research and teaching: changing relationships in a changing context, Studies in Higher Education, 24(3), pp.291-301.

Brew, A. (2001) The Nature of Research: Inquiry in academic contexts (London: Routledge Falmer).

Brew, A (2003) Teaching and research: new relationships and their implications for inquiry-based teaching and learning in higher education, Higher Education Research \& Development 22(1), 3-18

Brew, A. (2006) Research and Teaching: Beyond the divide (London: PalgraveMacmillan).

Childs, P, Healey, M, Lynch K, McEwen L, Mason O'Connor K, Roberts C, and Short C (2007) Leading, promoting and supporting undergraduate research in the new university sector, National Teaching Fellowship Project http://www.heacademy.ac.uk/projects/detail/ntfsproject universityofgloucestershire. (Accessed 16 September 2008).

De Vaus, D.E. (2002) Surveys in Social Research (London: Routledge).

DfES (Department for Education \& Skills) (2003) The Future for Higher Education (Norwich: The Stationery Office). http://www.dfes.gov.uk/hegateway/uploads/White\%20Pape.pdf. (Accessed 16 September 2008).

DfES (2004) HEFCE Grant Letter. http://www.hefce.ac.uk/news/hefce/2004/grantletter/letter.asp. (Accessed 16 September 2008).

Durning, B. \& Jenkins, A. (2005) Teaching/research relations in departments: the perspectives of built environment academics, Studies in Higher Education, 30 (4), pp.407-426.

Elton, L. (2001) Research and teaching: what are the real relationships?, Teaching in Higher Education, 6 (1), pp.43-56.

Foskett, N. and Roberts, D. and Maringe, F. (2006) Changing fee regimes and their impact on student attitudes to higher education (York: Higher Education Academy).

Griffiths, R. (2004) Knowledge production and the research-teaching nexus: the case of the built environment disciplines, Studies in Higher Education 29(6), 709-726.

Harrington, J. \& Booth, C. (2003) Research methods courses in undergraduate business programmes: An investigation. Report to the Learning and Teaching Support Network Business Education Support Team http://www.heacademy.ac.uk/assets/bmaf/documents/Resources/BEST Resources for websi te1.doc. (Accessed 16 September 2008).

Hattie, J. \& Marsh, H. W. (1996) The relationship between research and teaching: A metaanalysis, Review of Educational Research, 66 (4), pp.507-542.

Healey M. (2005a) Linking research and teaching: disciplinary spaces, in: R. Barnett (Ed.) Reshaping the university: new relationships between research, scholarship and teaching pp.30-42 (McGraw-Hill/Open University Press).

Healey, M. (2005b) Linking research and teaching to benefit student learning, Journal of Geography in Higher Education, 29 (2), pp.183-201. 
Jenkins, A. (1995) The impact of research assessment exercises on teaching in selected geography departments in England and Wales, Geography, 80, pp.367-374.

Jenkins, A., Blackman, T., Lindsay, R. \& Paton-Saltzberg, R. (1998) Teaching and research: Student perspectives and policy implications, Studies in Higher Education, 23 (2), pp.127-141. Jenkins, A., Breen, R., \& Lindsay, R. with Brew, A. (2003) Re-shaping Higher Education: Linking teaching and research (London: Routledge / SEDA).

Jenkins, A. \& Healey, M. (2005) Institutional Strategies to Link Teaching and Research (York: The Higher Education Academy).

http://www.heacademy.ac.uk/assets/York/documents/ourwork/research/Institutional strategies.pdf. (Accessed 16 September 2008).

Jenkins, A. \& Healey, M. (2009) Developing the student as a researcher through the curriculum, in Rust C (ed) Improving Student Learning through the Curriculum, Oxford Centre for Staff and Learning Development, Oxford Brookes University (Oxford: OCSLD).

Jenkins, A., Healey, M. \& Zetter, R. (2007) Linking Research and Teaching in Disciplines and Departments (York: Higher Education Academy). http://www.heacademy.ac.uk/ourwork/research/teaching

Kinkead, J (Ed.) (2003) Valuing and Supporting Undergraduate Research, New Directions for Teaching and Learning 93 (San Francisco: Jossey-Bass).

Kreber, C. (Ed.) (2006) Exploring research-based teaching, New Directions in Teaching and Learning (San Francisco: Jossey-Bass).

Lee, R. (2004) Research and teaching: making - or breaking - the links, Planet 12, pp.9-10.

Le Heron, R., Baker, R. \& McEwen, L. with other members of the INLT Linking Teaching and Research Group (2006) Co-learning: re-linking research and teaching in geography, Journal of Geography in Higher Education 30(1), pp.77-87.

Lindsay, R., Breen, R. \& Jenkins, A. (2002) Academic research and teaching quality: the views of undergraduate and postgraduate students, Studies in Higher Education, 27(3), pp.309-327.

McNeill, P. (1990) Research Methods (2nd edition) (London: Routledge).

Neumann, R. (1994) The teaching-research nexus: applying a framework to university students' learning experiences, European Journal of Education, 29 (2), pp.323-39.

Pell B. (2003) Student Experiences of the Relationship between Teaching and Research/Consultancy: the case of a new university, MA(res) thesis, University of Gloucestershire.

Pocklington, T. \& Tupper, A. (2002) No Place to Learn: Why Universities Aren't Working (Vancouver, BC: University of British Columbia Press).

Research Forum (2004) Forum's advice to Ministers on Teaching and Research http://www.dfes.gov.uk/hegateway/hereform/heresearchforum/index.cfm.

Robertson, J. \& Blackler, G. (2006) Students' experiences of learning in a research environment, Higher Education Research and Development 25(3), pp.215-229.

Robertson, J. \& Bond, C. (2001) Experiences of the relation between teaching and research: what do academics value? Higher Education Research and Development, 20(1), pp.5-19.

Robertson, J. \& Bond, C. (2005) The research/teaching relation: A view from the 'edge', Higher Education, 50(3), pp.509-535.

Ryder, J. (2004) What can students learn from final year research projects? Bioscience Education E-journal 4, paper 2. http://www.bioscience.heacademy.ac.uk/journal/vol4/beej-42.htm. (Accessed 16 September 2008).

Seymour, E., Hunter, A., Laursen, S. L. \& Deantoni, T. (2004) Establishing the benefits of research experiences for undergraduates in the sciences: first findings from a three year study, Science Education, 88 (4), pp.493-534.

Turner, N., Wuetherick, B. and Healey, M. (2008) International perspectives on student awareness, experiences and perceptions of research: Implications for academic developers in implementing research-based teaching and learning, International Journal for Academic Development 13(3) forthcoming. 
Verburgh, A., Elen, J. \& Clays, K. (2006) The relation between teaching and research: the perception of first year students at the University of Leuven, Proceedings European University-Industry Network: European Models of Synergy between Teaching and Research in Higher Education, Estonia, 105-110.

Willis, D., Harper, J., \& Sawicka, T. (1999) Putting the worms back in the can: encouraging diversity in the teaching research nexus. Paper presented to HERDSA Annual International Conference, Melbourne, 12-15 July. Available at: http://www.herdsa.org.au/wpcontent/uploads/conference/1999/pdf/Willis.PDF. (Accessed 16 September 2008).

Willis, D. \& Harper, J. 2000: Looking for learning: postgraduate experiences of the teaching research nexus, In Proceedings of the Symposium on Teaching and Learning in Higher Education, National University of Singapore 6-7 July.

Zamorski, B. (2002) Research-led teaching and learning in higher education: a case, Teaching in Higher Education, 7 (4), pp.411-427. 
Table I Previous studies of the student experience of research

\begin{tabular}{|l|l|l|l|}
\hline Authors & $\begin{array}{l}\text { University(ies) } \\
\text { and country }\end{array}$ & $\begin{array}{l}\text { Student } \\
\text { coverage }\end{array}$ & Methods \\
\hline $\begin{array}{l}\text { Neumann } \\
(1994)\end{array}$ & $\begin{array}{l}\text { Range of } \\
\text { Australian }\end{array}$ & $\begin{array}{l}\text { Undergraduate } \\
\text { and doctoral }\end{array}$ & 28 interviews \\
\hline $\begin{array}{l}\text { Jenkins } \text { et al. } \\
(1998)\end{array}$ & $\begin{array}{l}\text { Oxford } \\
\text { Brookes, UK }\end{array}$ & Undergraduates & $\begin{array}{l}\text { Focus groups (4-6 students) } \\
\text { in eight disciplines }\end{array}$ \\
\hline $\begin{array}{l}\text { Breen \& } \\
\text { Lindsay } \\
(1999)\end{array}$ & $\begin{array}{l}\text { Oxford } \\
\text { Brookes, UK }\end{array}$ & $\begin{array}{l}\text { Final year } \\
\text { undergraduates }\end{array}$ & $\begin{array}{l}\text { A 71-item lickert } \\
\text { questionnaire to 100 } \\
\text { students }\end{array}$ \\
\hline $\begin{array}{l}\text { Willis \& } \\
\text { Harper } \\
\text { (2000) }\end{array}$ & $\begin{array}{l}\text { Victoria } \\
\text { University } \\
\text { Wellington, NZ }\end{array}$ & Postgraduates & $\begin{array}{l}\text { 952 questionnaires and one } \\
\text { focus group }\end{array}$ \\
\hline $\begin{array}{l}\text { Lindsay et al. } \\
(2002)\end{array}$ & $\begin{array}{l}\text { Oxford } \\
\text { Brookes, UK }\end{array}$ & $\begin{array}{l}\text { Taught Masters } \\
\text { students }\end{array}$ & $\begin{array}{l}\text { Focus groups (4-6 students) } \\
\text { in eight disciplines (plus } \\
\text { comparison with Jenkins et } \\
\text { al.,1998 study) }\end{array}$ \\
\hline $\begin{array}{l}\text { Blackmore \& } \\
\text { Cousin } \\
(2003)\end{array}$ & $\begin{array}{l}\text { University of } \\
\text { Warwick, UK }\end{array}$ & Undergraduates & $\begin{array}{l}\text { 9 student interviews } \\
\text { evaluating the } \\
\text { Undergraduate Research } \\
\text { Scholarship scheme }\end{array}$ \\
\hline $\begin{array}{l}\text { Zamorski } \\
\text { (2002) }\end{array}$ & $\begin{array}{l}\text { University of } \\
\text { East Anglia, } \\
\text { UK }\end{array}$ & Undergraduates & $\begin{array}{l}\text { 12 students research their } \\
\text { own and 96 peer's } \\
\text { experiences }\end{array}$ \\
\hline $\begin{array}{l}\text { Robertson } \\
\text { and Blackler } \\
\text { (2006) }\end{array}$ & $\begin{array}{l}\text { University of } \\
\text { Canterbury, NZ }\end{array}$ & $\begin{array}{l}\text { Undergraduates } \\
\text { and } \\
\text { postgraduates }\end{array}$ & $\begin{array}{l}\text { 34 interviews with first year } \\
\text { to doctoral students }\end{array}$ \\
\hline
\end{tabular}

Table II Email questionnaire responses

\begin{tabular}{|l|l|l|}
\hline 163 undergraduates & 108 female & 75 Business School (BS) \\
\hline 31 postgraduates & 81 male & $\begin{array}{c}46 \text { School of Leisure, Tourism, } \\
\text { Hospitality \& Sport (LTHS) }\end{array}$ \\
\hline & & 48 Other schools (OS) \\
\hline Total $^{*}=194$ & $189^{*}$ & $169^{*}$ \\
\hline
\end{tabular}

${ }^{*}$ Totals in each column do not equal the overall number of responses (196) due to missing data. 
Table III During your studies at the University have you gained experience of any of the following?

\begin{tabular}{|l|r|}
\hline Statement & $\begin{array}{r}\text { Response } \\
\%\end{array}$ \\
\hline Undertaking a dissertation or thesis & 72 \\
\hline $\begin{array}{l}\text { Undertaking an independent project as part or whole of a } \\
\text { module }\end{array}$ & 54 \\
\hline $\begin{array}{l}\text { Reading a research paper or report written by a member } \\
\text { of staff }\end{array}$ & 24 \\
\hline $\begin{array}{l}\text { Being involved in practical activities/fieldwork based on } \\
\text { research projects }\end{array}$ & 18 \\
\hline $\begin{array}{l}\text { Attending a University research seminar (not as part of a } \\
\text { module) }\end{array}$ & 8 \\
\hline $\begin{array}{l}\text { Being a subject/participant in a research project run by a } \\
\text { member of staff }\end{array}$ & 5 \\
\hline $\begin{array}{l}\text { Contributing to a research paper, report or other form of } \\
\text { research output }\end{array}$ & \\
\hline
\end{tabular}

Table IV From your experience has the involvement of staff who teach you in research had a positive impact on your learning in any of the following ways?

\begin{tabular}{|l|r|}
\hline Statement & $\begin{array}{r}\text { Response } \\
\%\end{array}$ \\
\hline Increased my understanding of the subject & 52 \\
\hline Stimulated my interest and enthusiasm for the subject & 42 \\
\hline Increased my awareness of methodological issues & 41 \\
\hline $\begin{array}{l}\text { Contributed to the developments of my research-related } \\
\text { skills }\end{array}$ & 31 \\
\hline $\begin{array}{l}\text { Motivated me to consider pursuing postgraduate } \\
\text { research in the same area. }\end{array}$ & 10 \\
\hline
\end{tabular}

Table V From your experience has the involvement of staff who teach you in research had a negative impact on your learning in any of the following ways?

\begin{tabular}{|l|r|}
\hline Statement & $\begin{array}{r}\text { Response } \\
\%\end{array}$ \\
\hline Lack of availability of these staff to see me & 8 \\
\hline $\begin{array}{l}\text { Apparent lack of interest by these staff in teaching and } \\
\text { facilitating my learning }\end{array}$ & 7 \\
\hline $\begin{array}{l}\text { Apparent inability by these staff to explain material in } \\
\text { ways which I can understand }\end{array}$ & 4 \\
\hline $\begin{array}{l}\text { Apparent lack of interest by these staff in supporting my } \\
\text { academic welfare }\end{array}$ & 4 \\
\hline $\begin{array}{l}\text { Their research interests distorting the content of what they } \\
\text { teach }\end{array}$ & 8 \\
\hline
\end{tabular}

